\title{
Association of fried food intake with prehypertension and hypertension: the Filipino women's diet and health study
}

\author{
Sherlyn Mae P. Provido', Grace P. Abris ${ }^{2}$, Sangmo Hong ${ }^{3}$, Sung Hoon Yu ${ }^{4}$, Chang Beom Lee ${ }^{4}$ and Jung Eun Lee ${ }^{5,65}$ \\ 'Department of Food and Nutrition, Sookmyung Women's University, Cheongpa-ro 47-gil 100, Yongsan-gu, Seoul 04310, Korea \\ ${ }^{2}$ School of Public Health, Loma Linda University, Loma Linda, California 92354, USA \\ ${ }^{3}$ Division of Endocrinology and Metabolism, Department of Internal Medicine, Hallym University Dongtan Sacred Heart Hospital, 7, Keunjaebong-gil, Hwaseong-si, \\ Gyeonggi 18450, Korea \\ ${ }^{4}$ Division of Endocrinology and Metabolism, Department of Internal Medicine, Hanyang University Guri Hospital, Hanyang University College of Medicine, 153 \\ Gyeongchun-ro, Guri 11923, Korea \\ ${ }^{5}$ Department of Food and Nutrition, College of Human Ecology, Seoul National University, 1 Gwanak-ro, Gwanak-gu, Seoul 08826, Korea \\ ${ }^{6}$ Research Institute of Human Ecology, Seoul National University, 1 Gwanak-ro, Gwanak-gu, Seoul 08826, Korea
}

BACKGROUND/OBJECTIVES: Few epidemiological studies examined the association between fried food intake and hypertension. This study examined whether fried food intake was associated with higher prevalence of prehypertension and hypertension combined in a cross-sectional study of the Filipino Women's Diet and Health Study (FiLWHEL).

SUBJECTS/METHODS: This study included a total of 428 women aged 20-57 years who have ever been married to Korean men. Prehypertension was defined as $120-<140 \mathrm{mmHg}$ of SBP or $80-<90 \mathrm{mmHg}$ of DBP and hypertension as SBP $\geq 140$ $\mathrm{mmHg}$ or DBP $\geq 90 \mathrm{mmHg}$. Fried food intake was assessed using one-day 24-hour recall. Fried foods were categorized into total, deep/shallow and pan/stir fried foods. The odds ratio (OR)s and $95 \%$ confidence interval (Cl)s were calculated using multivariate logistic regression.

RESULTS: The prevalence of prehypertension and hypertension combined was $41.36 \%$ in this population. High fried food intake was associated with high prevalence of prehypertension and hypertension combined. The odds of having prehypertension and hypertension was higher in the 3rd tertile of fried food intake among fried food consumers compared to non-fried food consumers $(\mathrm{OR}=2.46,95 \% \mathrm{Cl}=1.24,4.87 ; P$ for trend $=0.004)$. Separate analysis for types of frying showed that deep and shallow fried food intake was associated with prevalence of prehypertension and hypertension combined for comparing the 3rd tertile vs. non-fried food consumers $(\mathrm{OR}=2.93 ; 95 \% \mathrm{Cl}=1.57-5.47 ; P$ for trend $=<0.001)$.

CONCLUSIONS: This study showed the evidence that high fried food intake was significantly associated with high prevalence of prehypertension and hypertension combined among Filipino women married to Korean men.

Nutrition Research and Practice 2020;14(1):76-84; https://doi.org/10.4162/nrp.2020.14.1.76; pISSN 1976-1457 elSSN 2005-6168

Keywords: Blood pressure, immigrants

\section{INTRODUCTION}

Hypertension is a worldwide public health challenge affecting approximately one billion individuals [1,2]. Globally, high blood pressure contributed to the 92 million or $6.0 \%$ of all disabilityadjusted life years (DALYs) among adults aged $\geq 45$ years old [3]. The World Health Organization (WHO) reported 1.13 billion adults aged $\geq 18$ years old had raised blood pressure in 2015 and the prevalence of hypertension among adults aged $\geq 20$ years old was predicted to increase from $52.7 \%$ (972 million) in 2000 to approximately $60 \%$, equating to 1.56 billion in 2025 $[1,4,5]$.

The American Heart Association (AHA) documented aging, being male, family history and genetics as non-modifiable risk factors for hypertension and high body mass index (BMI), physical inactivity, low income, smoking and tobacco use, excess intake of alcohol as modifiable risk factors [6,7]. A diet high in sodium, saturated fatty and trans-fatty acids, and added sugar was associated with an increase in blood pressure [8-10].

The US immigrant studies from national data found that Filipinos had the highest prevalence of hypertension and the highest hypertension mortality rate among Asian immigrants $[11,12]$. One study conducted among female marriage immigrants in Korea reported that Filipino women had the highest proportion of high blood pressure compared to Japanese, Chinese, Vietnamese, and Cambodians [13].

\footnotetext{
${ }^{\S}$ Corresponding Author: Jung Eun Lee, Tel. 82-2-880-6834, Fax. 82-2-884-0305, Email. jungelee@snu.ac.kr

Received: June 25, 2019, Revised: September 4, 2019, Accepted: October 15, 2019

* Our study was supported by Hanmi Pharmaceutical Co., Ltd, (No. 201300000001270) and Chong Kun Dang Pharm. Seoul, Korea (No. 201600000000225). Funding agencies played no role at all in the design or conduct of the study, the analyses, the interpretations of data, or in the preparation of this manuscript. This is an Open Access article distributed under the terms of the Creative Commons Attribution Non-Commercial License (http://creativecommons.org/licenses/by-nc/3.0/) which permits unrestricted non-commercial use, distribution, and reproduction in any medium, provided the original work is properly cited.
} 
Frying food is one of the most common and preferred cooking methods in the Philippines, probably because it is a convenient food preparation and fried food has a savory flavor favored by Filipinos [14,15]. During the frying process, the amount of oil absorbed into foods can reach up to $40 \%$ of the total weight of the food product $[16,17]$. Furthermore, during frying, the heated oil undergoes deterioration due to various chemical reactions like thermal oxidation, and thermally-oxidized oil induced oxidative stress [18]. Studies that examined the relationship of oxidative stress and endothelial dysfunction reported that oxidative stress was involved in the pathogenesis of endothelial dysfunction, one of the biological mechanisms responsible for the development of hypertension [19-22].

A cohort study in Spain reported that frequent intake of fried food was associated with a higher risk of hypertension and with the central adiposity and high blood pressure [23,24]. Also, a Spanish cross-sectional study found that high fried food intake was associated with high prevalence of hypertension when these foods were fried with re-used oils [25]. Another crosssectional study in Korean adults suggested that frequent fried food intake was associated with high prevalence of hypertension among women [26].

Given the evidences that Filipino immigrants are at higher risk for hypertension and intake of fried food among Filipino women is common, this study aimed to examine the association of fried food intake and prehypertension and hypertension combined among Filipino women.

\section{SUBJETCS AND METHODS}

\section{Study population}

The present study is a cross-sectional study of fried food intake and the prevalence of elevated blood pressure among the Filipino Women's Diet and Health Study (FiLWHEL) participants. Data were collected from 504 Filipino women aged 19 years or above using structured questionnaires, including demographic, health-related behavior, medical history, quality of life, acculturation, anthropometric examination and biospecimen. More information regarding the description of the
FiLWHEL study design and methods have previously been published elsewhere [27-29].

Out of 504 participants, 76 were excluded because of no 24-hour recalls $(n=7)$, unusual energy intake (3 standard deviations above or below the log-transformed mean energy intake; $n=7)$, and only one BP measurement $(n=24)$ or self-reported physician diagnosis of hypertension or use of antihypertensive medication $(n=38)$. As a result, 428 participants were included in the analysis. Prior to participation, all study participants gave written informed consent. The Sookmyung Women's University Institutional Review Board (reference number SMWU-1311BR-012) approved this study.

\section{Dietary intake assessment}

Fried food intake was determined using the one-day 24-hour recall method through an in-person or via telephone interview. Fried food was defined as deep fried, shallow fried, pan fried and stir fried. The list of fried foods is presented in Table 1. The total fried food intake per person was estimated by summing the amount of all fried foods consumed at home or away from home.

Fried food percent energy intake was calculated as total energy intakes from fried food ( $\mathrm{kcal} /$ day) divided by total energy intakes from all food (kcal/day) multiplied by 100 . Fried food (grams/day) per $1,000 \mathrm{kcal}$ of total energy intake was also calculated. Collected data were coded using the Computer Aided Nutritional Analysis Program version 4.0 for professional (CAN-pro 4.0). The nutrition information of some food items that were not available in CAN-pro software were derived from the U.S. Department of Agriculture (USDA) [30], Rural Development Administration (RDA) of Korea [31], Food and Nutrition Research Institute (FNRI) of the Philippines (specifically for Filipino foods) [32] or the manufacturer's product's nutritional label.

\section{Blood pressure measurements}

In accordance with the standard principle of blood pressure measurement, mercury sphygmomanometer was used to measure blood pressure with at least 5-minute rest while the participant was seated calmly. Using the same arm, two blood

Table 1. A list of fried foods

\begin{tabular}{|c|c|c|}
\hline No. & List of fried foods & Sub-group of fried foods \\
\hline 1 & Cutlets & fried breaded fish cutlet, fried breaded pork cutlet, fried breaded cheese cutlet, and fried breaded chicken cutlet \\
\hline 2 & Fried meat & fried pork, fried chicken, fried beef, fried chicken nuggets, fried meatball, fried patty and fried hotdog or sausage \\
\hline 3 & Fried seafood & fried tempura, fried mussels or shellfish, fried squid, fried octopus, fried anchovy, fried laver, and fried fish \\
\hline 4 & Fried dumplings & fried dumplings \\
\hline 5 & Fried spring rolls & fried spring rolls \\
\hline 6 & Fried tubers & fried sweet potato fritters, french fries, and fried potato \\
\hline 7 & Fried bread & croquette (with meat or vegetable filling) and doughnuts \\
\hline 8 & Fried banana & fried saba (ripe) and turon (banana roll) \\
\hline 9 & Fried vegetables & fried chili (leaves or pepper), fried garlic stalk, fried mushroom, fried ampalaya, and fried chayote \\
\hline 10 & Fried canned foods & fried corned beef, fried ham, fried canned fish, and fried luncheon meat \\
\hline 11 & Fried noodles & ramyeon \\
\hline 12 & Fried egg & sunny-side-up, scrambled, and rolled omelet \\
\hline 13 & Fried pancake & hotcake, sugar-filled pancake, leek or chives pancake, napa kimchi pancake, and bean sprout pancake \\
\hline 14 & Fried rice & fried rice \\
\hline 15 & Other fried foods & fried cheese stick, popcorn, and fried tofu \\
\hline
\end{tabular}


pressure readings with a 5-minute interval after the first measurement were obtained and the average of the two readings was used for the analysis. Elevated blood pressure was categorized into prehypertension with systolic blood pressure (SBP) of $120-<140 \mathrm{mmHg}$ or diastolic blood pressure (DBP) of $80-<90 \mathrm{mmHg}$ and hypertension with SBP of $\geq 140$ or DBP of $\geq 90 \mathrm{mmHg}$ or the used of antihypertensive medication [7]

\section{Anthropometric measurements}

Height and waist circumference were measured to the nearest $0.1 \mathrm{~cm}$ using a stretch-resistant tape measure with the participant in standing position. Waist circumference was measured at midpoint between the lowest border of the rib cage and the upper most lateral border of the right iliac crest. To measure body weight, bioelectric impedance analysis machine (InBody 620, Biospace Co. Ltd, Seoul, Korea) was used. BMl was calculated as weight in kilograms $(\mathrm{kg})$ divided by square of height in meters $\left(\mathrm{m}^{2}\right)$. Details of anthropometric measurements have been published elsewhere [27].

\section{Statistical analysis}

Participants were classified into blood pressure categories: normotensive and pre-hypertensive and hypertensive combined. For fried food intake, participants were categorized into non-fried food consumers and tertile levels among fried food consumers. Deep and shallow fried food intake and pan and stir fried food intake were also analyzed separately. Non-fried food consumers were considered as the referent category. Analysis of variance (ANOVA) and chi-square test were used to compare the means and proportions of baseline characteristics of the study participants according to fried food intake. Odds ratios (ORs) and 95\% confidence intervals (Cls) were calculated using multivariate logistic regression models. Tests for linear trend across increasing categories of fried food intake were conducted by assigning medians of the intake of fried food within each category and treating this variable as a continuous variable. The multivariate analysis was adjusted for age (years, continuous), energy intake (kcal/day, continuous), education level (high school or below, college or above-category), length of stay in South Korea (years, continuous), smoking status (ever, never-category), and alcohol intake (ever, never-category). BMI $\left(<23\right.$ and $\left.\geq 23 \mathrm{~kg} / \mathrm{m}^{2}\right)$ was adjusted in the additional analysis using the WHO Asia-Pacific cut-off points for overweight [33]. When we further adjusted for vigorous physical activities (hours/day, continuous), sodium intake (grams/day, continuous) and sleeping hours $(<5$ hours, 5-6 hours, 7-8 hours, $>8$ hours-category), we did not observe appreciable change in the estimates and therefore we did not include those variables in the model. Interactions were examined using the Likelihood Ratio Test (LRT) by including a cross-product term in the model. All $P$-values presented were two-tailed and $P<0.05$ was considered to be statistically significant. All analyses were performed using SAS version 9.4 software package (SAS Institute Inc., Cary, NC, USA).

\section{RESULTS}

Characteristics of participants according to fried food intake

A total of 428 women (mean \pm SD age: $33.77 \pm 7.78 \mathrm{yrs}$ ) were included in the analysis. The prevalence was $28.04 \%(n=120)$ for prehypertension $(120-<140 \mathrm{mmHg}$ of SBP or $80-<90$ $\mathrm{mmHg}$ of DBP) and $13.32 \%(n=57)$ for hypertension $(\geq 140$ $\mathrm{mmHg}$ of SBP or $\geq 90 \mathrm{mmHg}$ of DBP). Among fried food consumers, their mean intake values were $199.72 \mathrm{~g} / \mathrm{d}$ for total fried food, $165.92 \mathrm{~g} / \mathrm{d}$ for deep and shallow fried food and $134.26 \mathrm{~g} / \mathrm{d}$ for pan and stir fried food. Fried food consumers were younger and tended to consume more fast food compared to non-fried food consumers (Table 2). Intakes of total

Table 2. Characteristics of study participants according to fried food intake $(n=428)$

\begin{tabular}{|c|c|c|c|c|c|}
\hline & \multirow{2}{*}{$\begin{array}{l}\text { Non-fried food } \\
\text { consumer }\end{array}$} & \multicolumn{3}{|c|}{ Fried food consumer (\% energy intake) } & \multirow{2}{*}{$P$-value ${ }^{1), 2}$} \\
\hline & & Tertile 1 & Tertile 2 & Tertile 3 & \\
\hline Age (yrs) & $35.04 \pm 8.40$ & $34.65 \pm 7.90$ & $33.22 \pm 7.21$ & $32.13 \pm 7.52$ & 0.03 \\
\hline BMI $\left(\mathrm{kg} / \mathrm{m}^{2}\right)^{3)_{*}}$ & $23.41 \pm 3.23$ & $23.44 \pm 4.02$ & $23.32 \pm 3.57$ & $23.75 \pm 3.88$ & 0.84 \\
\hline Waist circumference $(\mathrm{cm})^{3) *}$ & $79.45 \pm 8.60$ & $79.28 \pm 9.96$ & $78.58 \pm 8.51$ & $79.96 \pm 10.01$ & 0.74 \\
\hline Smoking status $(\mathrm{n}, \%)^{*}$ & & & & & 0.74 \\
\hline Never & $74(89.16)$ & 107 (93.04) & $99(90.00)$ & $105(92.11)$ & \\
\hline Ever & $9(10.84)$ & $8(6.96)$ & $11(10.00)$ & $9(7.89)$ & \\
\hline Alcohol intake $(\mathrm{n}, \%)^{*}$ & & & & & 0.14 \\
\hline Never & $18(21.69)$ & $34(29.57)$ & $38(34.23)$ & $26(22.81)$ & \\
\hline Ever & $65(78.31)$ & $81(70.43)$ & $73(65.77)$ & $88(77.19)$ & \\
\hline Education $(n, \%)^{*}$ & & & & & 0.18 \\
\hline High school or below & $28(33.73)$ & $30(26.09)$ & $41(36.28)$ & $45(39.13)$ & \\
\hline College or above & $55(66.27)$ & $85(73.91)$ & $72(63.72)$ & $70(60.87)$ & \\
\hline Length of stay in Korea (yrs)* & $8.29 \pm 5.66$ & $8.55 \pm 5.42$ & $7.55 \pm 4.78$ & $6.96 \pm 4.61$ & 0.09 \\
\hline Fast Food (n, \%) & & & & & $<0.001$ \\
\hline No & $70(84.34)$ & $80(69.57)$ & $62(53.91)$ & $61(53.04)$ & \\
\hline Yes & $13(15.66)$ & $35(30.43)$ & $53(46.09)$ & $54(49.96)$ & \\
\hline Energy intake from fried food (\%) & - & $7.32 \pm 3.80$ & $20.34 \pm 4.53$ & $44.57 \pm 13.50$ & $<0.001$ \\
\hline Fried food intake $(\mathrm{g} / \mathrm{d})$ & - & $84.92 \pm 61.58$ & $183.82 \pm 105.09$ & $330.43 \pm 177.04$ & $<0.001$ \\
\hline Total caloric intake (kcal/d) & $1,473.93 \pm 615.67$ & $1,936.47 \pm 693.93$ & $1,918.38 \pm 752.11$ & $1,808.82 \pm 704.95$ & $<0.001$ \\
\hline
\end{tabular}


Table 2. continued

\begin{tabular}{|c|c|c|c|c|c|}
\hline & \multirow{2}{*}{$\begin{array}{l}\text { Non-fried food } \\
\text { consumer }\end{array}$} & \multicolumn{3}{|c|}{ Fried food consumer (\% energy intake) } & \multirow{2}{*}{$P$-value ${ }^{1), 2)}$} \\
\hline & & Tertile 1 & Tertile 2 & Tertile 3 & \\
\hline Carbohydrate intake (\% energy intake) & $58.51 \pm 14.21$ & $58.81 \pm 12.35$ & $57.65 \pm 10.56$ & $51.93 \pm 9.29$ & $<0.001$ \\
\hline Protein intake (\% energy intake) & $15.80 \pm 4.89$ & $15.45 \pm 4.21$ & $16.20 \pm 4.72$ & $16.47 \pm 4.48$ & 0.36 \\
\hline Fat intake (\% energy intake) & $25.24 \pm 11.86$ & $25.16 \pm 9.56$ & $26.39 \pm 8.14$ & $31.10 \pm 7.68$ & $<0.001$ \\
\hline Sodium intake (mg/d) & $2,367.42 \pm 2,067.52$ & $3,328.42 \pm 2,244.17$ & $3,143.34 \pm 1,865.62$ & $3,274.37 \pm 2,188.69$ & 0.007 \\
\hline Potassium intake $(\mathrm{mg} / \mathrm{d})$ & $1,893.19 \pm 966.49$ & $2,443.33 \pm 1,101.59$ & $2,440.67 \pm 1,343.57$ & $2,059.58 \pm 1,043.04$ & $<0.001$ \\
\hline Cholesterol intake (mg/d) & $263.54 \pm 404.40$ & $341.12 \pm 289.90$ & $319.35 \pm 241.78$ & $382.98 \pm 300.18$ & 0.06 \\
\hline
\end{tabular}

1) $P$-value for continuous was determined by ANOVA: mean $\pm \mathrm{SD}$ (Standard deviation)

2) $P$-value for categorical was determined by Chi-square test

3) BMl: Body Mass Index

* Due to missing data, number of participants may not sum up to 428 .

Table 3. Odds ratio and $95 \%$ confidence interval of prehypertension and hypertension combined according to fried food intake

\begin{tabular}{|c|c|c|c|c|c|}
\hline & \multirow{2}{*}{$\begin{array}{l}\text { Non-fried food } \\
\text { consumer }\end{array}$} & \multicolumn{3}{|c|}{ Fried food intake } & \multirow{2}{*}{$P$ for trend } \\
\hline & & Tertile 1 & Tertile 2 & Tertile 3 & \\
\hline \multicolumn{6}{|l|}{ Percent energy intake } \\
\hline No. of cases/Total $\mathrm{N}$ & $33 / 83$ & $45 / 115$ & $43 / 115$ & $56 / 115$ & \\
\hline Median intake & 0 & 7.88 & 19.41 & 41.02 & \\
\hline Age-adjusted & 1.00 & $1.03(0.55-1.93)$ & $1.11(0.59-2.08)$ & $2.17(1.15-4.09)$ & 0.005 \\
\hline Multivariate-adjusted $^{1}$ & 1.00 & $1.03(0.54-1.96)$ & $1.17(0.62-2.22)$ & $2.24(1.17-4.26)$ & 0.004 \\
\hline Multivariate-adjusted $^{2}$ & 1.00 & $1.18(0.61-2.31)$ & $1.28(0.65-2.51)$ & $2.46(1.24-4.87)$ & 0.004 \\
\hline \multicolumn{6}{|l|}{ Grams per day } \\
\hline No. of cases/Total $\mathrm{N}$ & $33 / 83$ & $40 / 115$ & $53 / 115$ & $51 / 115$ & \\
\hline Median intake & 0 & 62.90 & 156.00 & 335.00 & \\
\hline Age-adjusted & 1.00 & $0.89(0.47-1.68)$ & $1.52(0.82-2.84)$ & $1.75(0.93-3.27)$ & 0.02 \\
\hline Multivariate-adjusted $^{1}$ & 1.00 & $0.94(0.49-1.80)$ & $1.50(0.80-2.84)$ & $1.84(0.97-3.47)$ & 0.02 \\
\hline Multivariate-adjusted $^{2}$ & 1.00 & $1.07(0.54-2.11)$ & $1.58(0.81-3.07)$ & $2.13(1.09-4.18)$ & 0.01 \\
\hline \multicolumn{6}{|c|}{ Grams per $1000 \mathrm{kcal}$ of total energy intakes } \\
\hline No. of cases/Total $\mathrm{N}$ & $33 / 83$ & $47 / 115$ & $49 / 115$ & $48 / 115$ & \\
\hline Median intake & 0 & 40.18 & 89.56 & 185.29 & \\
\hline Age-adjusted & 1.00 & $1.05(0.56-1.96)$ & $1.37(0.74-2.57)$ & $1.69(0.90-3.19)$ & 0.06 \\
\hline Multivariate-adjusted $^{1)}$ & 1.00 & $1.10(0.58-2.08)$ & $1.39(0.74-2.62)$ & $1.76(0.92-3.37)$ & 0.05 \\
\hline Multivariate-adjusted $^{2)}$ & 1.00 & $1.26(0.64-2.46)$ & $1.50(0.77-2.92)$ & $1.95(0.99-3.84)$ & 0.05 \\
\hline
\end{tabular}

1) Adjusted for age (years, continuous), education (high school or below, college or above), length of stay in Korea (years, continuous), smoking status (ever, never), and alcohol intake (ever, never)

${ }^{2}$ Adjusted for age (years, continuous), education (high school or below, college or above), length of stay in Korea (years, continuous), smoking status (ever, never), alcohol intake (ever, never), and $\mathrm{BMl}\left(<23, \geq 23 \mathrm{~kg} / \mathrm{m}^{2}\right)$

Table 4. Odds ratio and $95 \%$ confidence interval of hypertension according to fried food intake

\begin{tabular}{|c|c|c|c|c|c|}
\hline & \multirow{2}{*}{$\begin{array}{l}\text { Non-fried food } \\
\text { consumer }\end{array}$} & \multicolumn{3}{|c|}{ Fried food consumer (\% energy intake) } & \multirow{2}{*}{$P$ for trend } \\
\hline & & Tertile 1 & Tertile 2 & Tertile 3 & \\
\hline No. of cases/Total $\mathrm{N}$ & $11 / 83$ & $14 / 155$ & $16 / 115$ & $16 / 155$ & \\
\hline Median & 0 & 7.88 & 19.41 & 41.02 & \\
\hline Age-adjusted & 1.00 & $0.97(0.39-2.41)$ & $1.48(0.61-3.61)$ & $1.63(0.66-4.02)$ & 0.18 \\
\hline Multivariate-adjusted $^{1)}$ & 1.00 & $1.03(0.41-2.57)$ & $1.62(0.66-4.02)$ & $1.63(0.65-4.10)$ & 0.21 \\
\hline Multivariate-adjusted ${ }^{2)}$ & 1.00 & $1.28(0.50-3.28)$ & $1.85(0.72-4.72)$ & $1.75(0.68-4.50)$ & 0.23 \\
\hline
\end{tabular}

${ }^{1)}$ Adjusted for age (years, continuous), education (high school or below, college or above), length of stay in Korea (years, continuous), smoking status (ever, never), and alcohol intake (ever, never)

${ }^{2)}$ Adjusted for age (years, continuous), education (high school or below, college or above), length of stay in Korea (years, continuous), smoking status (ever, never), alcohol intake (ever, never), and $\mathrm{BMl}\left(<23, \geq 23 \mathrm{~kg} / \mathrm{m}^{2}\right)$

energy, fat, sodium, potassium, and cholesterol were higher among high fried food consumers but lower in carbohydrate intake as compared to non-fried food consumers.
Association between fried food intake and prehypertension and hypertension combined

High fried food intake was associated with high prevalence of prehypertension and hypertension combined (Table 3). 
Table 5. Odds ratio and $95 \%$ confidence interval of prehypertension and hypertension combined according to deep/shallow and pan/stir fried food

\begin{tabular}{|c|c|c|c|c|c|c|}
\hline & \multirow{2}{*}{$\begin{array}{l}\text { Mean } \\
(g / d)\end{array}$} & \multirow{2}{*}{$\begin{array}{l}\text { Non-fried food } \\
\text { consumer }\end{array}$} & \multicolumn{3}{|c|}{ Fried food (\% energy intake) } & \multirow{2}{*}{$P$ for trend } \\
\hline & & & Tertile 1 & Tertile 2 & Tertile 3 & \\
\hline Deep and shallow fry & 165.62 & & & & & \\
\hline No. of cases/Total $\mathrm{N}$ & & $70 / 183$ & $32 / 81$ & $32 / 82$ & $43 / 82$ & \\
\hline Median & & 0 & 8.03 & 18.69 & 36.28 & \\
\hline Age-adjusted & & 1.00 & $1.15(0.64-2.05)$ & $1.22(0.69-2.18)$ & $2.33(1.32-4.14)$ & 0.005 \\
\hline Multivariate-adjusted ${ }^{1}$ & & 1.00 & $1.19(0.66-2.15)$ & $1.33(0.74-2.39)$ & $2.48(1.38-4.46)$ & 0.003 \\
\hline Multivariate-adjusted $^{2}$ & & 1.00 & $1.38(0.75-2.54)$ & $1.61(0.87-2.98)$ & $2.93(1.57-5.47)$ & $<0.001$ \\
\hline Pan and stir fry & 134.26 & & & & & \\
\hline No. of cases/Total $\mathrm{N}$ & & $92 / 217$ & $28 / 70$ & $35 / 71$ & $22 / 70$ & \\
\hline Median & & 0 & 3.24 & 10.54 & 23.82 & \\
\hline Age-adjusted & & 1.00 & $0.74(0.41-1.33)$ & $1.51(0.85-2.69)$ & $0.74(0.40-1.36)$ & 0.67 \\
\hline Multivariate-adjusted ${ }^{1)}$ & & 1.00 & $0.80(0.44-1.45)$ & $1.52(0.84-2.75)$ & $0.74(0.39-1.38)$ & 0.66 \\
\hline Multivariate-adjusted $^{2)}$ & & 1.00 & $0.86(0.46-1.61)$ & $1.28(0.70-2.36)$ & $0.60(0.31-1.17)$ & 0.25 \\
\hline
\end{tabular}

1) Adjusted for age (years, continuous), education (high school or below, college or above), length of stay in Korea (years, continuous), smoking status (ever, never), and alcohol intake (ever, never)

${ }^{2)}$ Adjusted for age (years, continuous), education (high school or below, college or above), length of stay in Korea (years, continuous), smoking status (ever, never), alcohol intake (ever, never), and BMl $\left(<23, \geq 23 \mathrm{~kg} / \mathrm{m}^{2}\right)$

Table 6. Odds ratio and $95 \%$ confidence interval of prehypertension and hypertension combined according to fried food intake by age, waist circumference, BMl, education, and length of stay in Korea

\begin{tabular}{|c|c|c|c|c|c|c|c|}
\hline & & \multirow{2}{*}{$\begin{array}{l}\text { Non-fried food } \\
\text { consumer }\end{array}$} & \multicolumn{3}{|c|}{ Fried food (\% energy) } & \multirow{2}{*}{$P$ for trend } & \multirow{2}{*}{$\begin{array}{c}P \text { for } \\
\text { heterogeneity }\end{array}$} \\
\hline & & & Tertile 1 & Tertile 2 & Tertile 3 & & \\
\hline Age & & & & & & & 0.46 \\
\hline \multirow[t]{2}{*}{$<40$ yrs } & No. of cases/Total $\mathrm{N}$ & $17 / 59$ & $27 / 86$ & $24 / 92$ & $43 / 98$ & & \\
\hline & OR $(95 \% \mathrm{Cl})$ & 1.00 & $1.04(0.49-2.21)$ & $0.88(0.41-1.87)$ & $2.08(1.01-4.27)$ & 0.01 & \\
\hline \multirow[t]{2}{*}{$\geq 40$ yrs } & No. of cases/Total $\mathrm{N}$ & $16 / 24$ & $18 / 29$ & $19 / 23$ & $13 / 17$ & & \\
\hline & OR $(95 \% \mathrm{Cl})$ & 1.00 & $0.90(0.28-2.90)$ & $3.34(0.77-14.49)$ & $1.79(0.40-8.06)$ & 0.20 & \\
\hline WC & & & & & & & 0.53 \\
\hline \multirow[t]{2}{*}{$<85 \mathrm{~cm}$} & No. of cases/Total $\mathrm{N}$ & $23 / 65$ & $27 / 86$ & $28 / 87$ & $33 / 82$ & & \\
\hline & OR $(95 \% \mathrm{Cl})$ & 1.00 & $0.71(0.33-1.51)$ & $0.96(0.45-2.02)$ & $1.67(0.79-3.54)$ & 0.04 & \\
\hline \multirow[t]{2}{*}{$\geq 85 \mathrm{~cm}$} & No. of cases/Total $\mathrm{N}$ & $18-10$ & $18 / 29$ & $15 / 28$ & $23 / 33$ & & \\
\hline & OR $(95 \% \mathrm{Cl})$ & 1.00 & $2.23(0.56-8.87)$ & 1.89 (0.49-7.33) & $3.31(0.81-13.43)$ & 0.16 & \\
\hline BMI & & & & & & & 0.10 \\
\hline \multirow[t]{2}{*}{$<23 \mathrm{~kg} / \mathrm{m}^{2}$} & No. of cases/Total $\mathrm{N}$ & $8 / 35$ & $18 / 60$ & $16 / 57$ & $12 / 55$ & & \\
\hline & OR $(95 \% \mathrm{Cl})$ & 1.00 & $1.15(0.40-3.28)$ & $1.52(0.53-4.37)$ & $1.27(0.42-3.81)$ & 0.66 & \\
\hline \multirow[t]{2}{*}{$\geq 23 \mathrm{~kg} / \mathrm{m}^{2}$} & No. of cases/Total $\mathrm{N}$ & $25 / 48$ & $27 / 55$ & $27 / 58$ & $44 / 60$ & & \\
\hline & OR $(95 \% \mathrm{Cl})$ & 1.00 & $1.16(0.48-2.79)$ & $1.14(0.48-2.73)$ & $4.09(1.62-10.31)$ & $<0.001$ & \\
\hline Education & & & & & & & 0.07 \\
\hline \multirow[t]{2}{*}{ High school or below } & No. of cases/Total $\mathrm{N}$ & $13 / 28$ & $30-12$ & $12 / 41$ & $18 / 45$ & & \\
\hline & OR $(95 \% \mathrm{Cl})$ & 1.00 & $0.77(0.24-2.44)$ & $0.69(0.23-2.13)$ & $0.98(0.33-2.92)$ & 0.83 & \\
\hline \multirow[t]{2}{*}{ College or above } & No. of cases/Total $\mathrm{N}$ & $20 / 55$ & $33 / 85$ & $31 / 72$ & $38 / 70$ & & \\
\hline & OR $(95 \% \mathrm{Cl})$ & 1.00 & $1.20(0.55-2.61)$ & $1.50(0.68-3.34)$ & $3.30(1.46-7.47)$ & 0.001 & \\
\hline Length of stay in Kore & & & & & & & 0.66 \\
\hline \multirow[t]{2}{*}{$<10$ yrs } & No. of cases/Total $\mathrm{N}$ & $15 / 53$ & $16 / 71$ & $23 / 73$ & $31 / 80$ & & \\
\hline & OR $(95 \% \mathrm{Cl})$ & 1.00 & $0.66(0.28-1.58)$ & $1.26(0.55-2.89)$ & $1.98(0.89-4.42)$ & 0.01 & \\
\hline \multirow[t]{2}{*}{$\geq 10 \mathrm{yrs}$} & No. of cases/Total $\mathrm{N}$ & $18 / 30$ & $28 / 41$ & $20 / 38$ & $24 / 32$ & & \\
\hline & OR $(95 \% \mathrm{Cl})$ & 1.00 & $1.65(0.59-4.60)$ & $0.89(0.32-2.45)$ & $2.24(0.72-7.02)$ & 0.30 & \\
\hline
\end{tabular}

Adjusted for age (years, continuous), education (high school or below, college or above), length of stay in Korea (years, continuous), smoking status (ever, never), and alcohol intake (ever, never), and $\mathrm{BMl}\left(<23, \geq 23 \mathrm{~kg} / \mathrm{m}^{2}\right)$

Compared to non-fried food consumers, the multivariateadjusted ORs and 95\% Cls for having elevated blood pressure among fried food consumers were 1.03 (95\% Cl: 0.54-1.96) in the 1st tertile, 1.17 (95\% Cl: 0.62-2.22) in the 2nd tertile, and
2.24 (95\% Cl: 1.17-4.26) in the 3rd tertile of fried food intake (\% energy intake) ( $P$ for trend $=0.004)$. When adjusted for BMI, compared to non-fried food consumers, the ORs and $95 \% \mathrm{Cls}$ for the 1st, 2nd, and 3rd tertiles were 1.18 (0.61-2.31), 1.28 (0.65- 
$2.51)$ and 2.46 (1.24-4.87), respectively, ( $P$ for trend $=0.004)$. A similar pattern was observed when fried food intake as grams per day or grams per $1,000 \mathrm{kcal}$ of total energy intake was analyzed. When only hypertension was considered as an endpoint, the prevalence was still higher, albeit not statistically significant (Table 4), comparing the 3rd tertile of fried food consumers with non-fried food consumers.

For the separate analyses of deep and shallow fried food intake or pan and stir fried food intake, there was a high prevalence of prehypertension and hypertension combined limited to deep and shallow fried food (Table 5); ORs (95\% Cls) for the 1st, 2nd, and 3rd tertiles of fried food intake were 1.19 (0.66-2.15), 1.33 (0.74-2.39) and 2.48 (1.38-4.46), respectively, ( $P$ for trend $=0.003$ ). When $\mathrm{BMl}$ was added to the multivariate model, compared to non-fried food consumers, the ORs and 95\% Cls for the 1st, 2nd, and 3rd tertiles were $1.38(0.75-2.54)$, 1.61 (0.87-2.98), and 2.93 (1.57-5.47), respectively, ( $P$ for trend $=<0.001)$. However, the tertiles of pan and stir fried food consumers were compared to non-fried food consumers, there was no significant association.

Interaction by age, obesity, education and length of stay

Examination of whether the association of fried food intakes and prehypertension and hypertension combined was modified by age, anthropometric measures, education, and length of stay in South Korea, revealed that there was only a borderline significant interaction with education $(P$ for heterogeneity $=$ 0.07) (Table 6). The association was more pronounced among those who graduated from college or above than those who graduated from high school or below. In addition, those with higher BMl tended to have high prevalence of prehypertension and hypertension combined with high fried food intake, but this pattern was not clear for those with lower BMI.

\section{DISCUSSION}

This study found that high fried food intake was associated with high prevalence of prehypertension and hypertension combined among Filipino women married to Korean men. Compared to non-fried food consumers, Filipino women in the highest tertile of fried food intake had a 2-fold higher prevalence of prehypertension and hypertension combined. The association was observed for deep and shallow fried food intake but not for pan and stir fried food intake. In addition, the association between fried food intake and prehypertension and hypertension combined was more apparent for Filipino women with a higher $\mathrm{BMl}$ or with higher education compared to those with a lower BMI or lower education, respectively.

Only a few epidemiologic studies examined the association between fried food intake and hypertension. The Seguimiento Universidad de Navarra (SUN) project, a prospective cohort from Spain, previously reported that frequent consumption of fried foods was associated with higher risk of developing hypertension among young adults after 6.3 years of follow-up. In that study, comparing those who consumed fried foods $<2$ times/week with those who consumed fried food $>2-4$ and $>4$ times/week, the relative risk (RR) were $1.18(95 \% \mathrm{Cl}: 1.03$, 1.36) and $1.21(95 \% \mathrm{Cl}: 1.04,1.41)$, respectively, $(P$ for trend $=$
0.009) [23]. Furthermore, another SUN study reported that, in comparison to those who consumed fried foods $>4$ times/week with $\leq 2$ times/week, after 8.3 years of follow-up, the RR for developing high blood pressure was 1.16 (95\% Cl: 1.02, 1.32; $P$ for trend $=0.011$ ) [24].

The present study showed similar findings to two crosssectional studies carried out in Spain and in Korea. The Spanish study found that fried food intake was associated with prevalence of hypertension, especially when degraded vegetable oils, such as sunflower oil, were re-used [25]. Also, prolonged intakes of the repeated heated oil has been reported to increase blood pressure [34]. However, in the present study, it was not possible to differentiate between the different type of oils or fats used to fry or if they ever use used oils in frying. In the 5th Korean National Health and Nutrition Survey (KNHANES) 2010-2011 of Korean adults, the prevalence of hypertension increased by 2.4-fold in women with $>2$ times/week fried food intake compared with those who rarely consumed it [26].

There are various possible mechanisms behind the blood pressure raising effect of heated oil. During frying, heated oil undergoes deterioration due to the exposure of oil to high temperatures in the presence of air and moisture [35,36]. Thermally-oxidized oil generates free radicals which in turn react with nitric oxide (NO), causing activation of peroxynitrite, which propagates the chain of lipid peroxidation [18,21,37] . Also, it has been reported that hypertensive individuals have high levels of malondialdehyde (MDA), a breakdown product of lipid peroxidation and a known marker of oxidative stress $[18,38]$. Several narrative reviews reported that oxidative stress instigates vascular inflammation by activating the nuclear factor kappa-light-chain-enhancer of activated B cells (NF-KB), promoting endothelial dysfunction which impairs the production of NO, increases vascular reactivity and resistance, as well as raises angiotensin II (Ang II) levels in vascular smooth muscle cells (VSMC), which may predispose risk of hypertension [18,22, $34,37,39]$.

In this study, we found high prevalence of hypertension with deep and shallow fried food, but not with pan and stir fried food. When oil is exposed to deep-frying temperature, it leads to a series of physicochemical changes such as production of volatile and non-volatile compounds, which affect the properties of oil and fried food $[21,35,40]$. Also, deep-frying generates toxic compounds such as hydroperoxides, aldehydes, and other free radicals. These toxic products are absorbed into the food, ingested into the gastrointestinal tract, eventually entering the circulatory system $[21,41,42]$. The frying method might have different effects on the absorption of fats depending on the food, food surface area, moisture content of food, the type of oil used, frying condition (time, temperature, fryer, etc.) and the degree of degradation $[25,43,44]$. However, we could not assess whether the oil used was fresh or re-used.

This, to our knowledge, is the first study to examine the association of fried food intake and hypertension among Filipino women. Another strength of our study is that we defined prehypertension or hypertension based on blood pressure levels measured by trained physicians. Nonetheless, the study has several limitations. First, the cross-sectional design cannot infer any causal relationship between fried food and elevated 
blood pressure or hypertension. Although the current evidence is from a cross-sectional study, it is still reasonable within the context of achieving optimum health to recommend reducing or eliminating frying foods as well as avoidance of consuming fried foods among Filipino women. Secondly, the relatively small sample size based on convenience sampling does not represent the general population. Thirdly, the data on fried foods were collected from a one-day 24-hour recall, which does not represent the usual daily intake and might have some non-differential measurement errors. Lastly, we did not investigate in detail the type of fat or oil used for frying from a take away restaurant or away from home.

In conclusion, this study showed the evidence that high fried food intake, especially deep and shallow fried food was significantly associated with high prevalence of prehypertension and hypertension combined among Filipino women. Further prospective studies are warranted on the association of fried food intake and cardiovascular risk factors among Filipino women.

\section{ACKNOWLEDGEMENTS}

We would like to extend our gratitude to the participants and the Filipino community leaders for their participation and for their continuous support of this study.

\section{CONFLICT OF INTEREST}

The authors declare no potential conflicts of interest.

\section{ORCID}

Sherlyn Mae P. Provido: https://orcid.org/0000-0001-5894-247X

Grace P. Abris: https://orcid.org/0000-0002-0483-7137

Sangmo Hong: https://orcid.org/0000-0002-8535-0565

Sung Hoon Yu: https://orcid.org/0000-0003-4391-4526

Chang Beom Lee: https://orcid.org/0000-0003-4891-834X

Jung Eun Lee: https://orcid.org/0000-0003-1141-878X

\section{REFERENCES}

1. Kearney PM, Whelton M, Reynolds K, Muntner P, Whelton PK, He J. Global burden of hypertension: analysis of worldwide data. Lancet 2005;365:217-23.

2. World Health Organization. A global brief on hypertension: silent killer, global public health crisis [Internet]. Geneva: World Health Organization; 2013 [cited 2018 August 23]. Available from: http:// www.who.int/cardiovascular_diseases/publications/global_brief_hy pertension/en/.

3. Lawes CM, Vander Hoorn S, Rodgers A; International Society of Hypertension. Global burden of blood-pressure-related disease, 2001. Lancet 2008;371:1513-8.

4. World Health Organization. Global Health Observatory (GHO) data: blood pressure [Internet]. Geneva: World Health Organization; 2017 [cited 2019 June 18]. Available from: https://www.who.int/gho/ncd/ risk_factors/blood_pressure_prevalence/en/.

5. Zhou B, Bentham J, Di Cesare M, Bixby H, Danaei G, Cowan MJ, Paciorek CJ, Singh G, Hajifathalian K, Bennett JE, Taddei C, Bilano V, Carrillo-Larco RM, Djalalinia S, Khatibzadeh S, Lugero C, Peykari
N, Zhang WZ, Lu Y, Stevens GA, Riley LM, Bovet P, Elliott P, Gu $D$, Ikeda $N$, Jackson RT, Joffres $M$, Kengne AP, Laatikainen $T$, Lam TH, Laxmaiah A, Liu J, Miranda JJ, Mondo CK, Neuhauser HK, Sundström J, Smeeth L, Soric M, Woodward M, Ezzati M, AbarcaGómez L, Abdeen ZA, Rahim HA, Abu-Rmeileh NM, Acosta-Cazares B, Adams R, Aekplakorn W, Afsana K, Aguilar-Salinas CA, Agyemang C, Ahmadvand A, Ahrens W, Al Raddadi R, Al Woyatan R, Ali MM, Alkerwi A, Aly E, Amouyel P, Amuzu A, Andersen LB, Anderssen $S A$, Ängquist L, Anjana RM, Ansong $D$, Aounallah-Skhiri $H$, Araújo J, Ariansen I, Aris T, Arlappa N, Aryal K, Arveiler D, Assah FK, Assunção MC, Avdicová M, Azevedo A, Azizi F, Babu BV, Bahijri S, Balakrishna N, Bandosz P, Banegas JR, Barbagallo CM, Barceló A, Barkat A, Barros AJ, Barros MV, Bata I, Batieha AM, Baur LA, Beaglehole R, Romdhane $H B$, Benet $M$, Benson LS, Bernabe-Ortiz A, Bernotiene $\mathrm{G}$, Bettiol H, Bhagyalaxmi A, Bharadwaj S, Bhargava SK, Bi Y, Bikbov $M$, Bjerregaard $P$, Bjertness $E$, Björkelund $C$, Blokstra A, Bo S, Bobak M, Boeing $H$, Boggia JG, Boissonnet CP, Bongard V, Braeckman L, Brajkovich I, Branca F, Breckenkamp J, Brenner $\mathrm{H}$, Brewster LM, Bruno G, Bueno-de-Mesquita HB, Bugge A, Burns $C$, Bursztyn M, de León AC, Cacciottolo J, Cameron C, Can G, Cândido AP, Capuano V, Cardoso VC, Carlsson AC, Carvalho MJ, Casanueva FF, Casas JP, Caserta CA, Chamukuttan S, Chan AW, Chan Q, Chaturvedi HK, Chaturvedi N, Chen $\mathrm{CJ}$, Chen F, Chen $\mathrm{H}$, Chen $\mathrm{S}$, Chen Z, Cheng CY, Dekkaki IC, Chetrit A, Chiolero A, Chiou ST, Chirita-Emandi A, Cho B, Cho Y, Chudek J, Cifkova R, Claessens F, Clays E, Concin H, Cooper C, Cooper R, Coppinger TC, Costanzo S, Cottel D, Cowell C, Craig CL, Crujeiras AB, Cruz JJ, D'Arrigo G, d'Orsi E, Dallongeville J, Damasceno A, Dankner R, Dantoft TM, Dauchet L, De Backer G, De Bacquer D, de Gaetano G, De Henauw S, De Smedt D, Deepa M, Dehghan A, Delisle H, Deschamps V, Dhana K, Di Castelnuovo AF, Dias-da-Costa JS, Diaz A, Dickerson TT, Do HT, Dobson AJ, Donfrancesco C, Donoso SP, Döring A, Doua K, Drygas W, Dulskiene V, Džakula A, Dzerve V, DziankowskaZaborszczyk E, Eggertsen R, Ekelund U, El Ati J, Ellert U, Elliott $P$, Elosua R, Erasmus RT, Erem C, Eriksen L, de la Peña JE, Evans A, Faeh $D$, Fall $\mathrm{CH}$, Farzadfar F, Felix-Redondo FJ, Ferguson TS, Fernández-Bergés $D$, Ferrante $D$, Ferrari $M$, Ferreccio $C$, Ferrieres $J$, Finn JD, Fischer $K$, Föger B, Foo LH, Forslund AS, Forsner $M$, Fortmann SP, Fouad HM, Francis DK, Franco MC, Franco $\mathrm{OH}$, Frontera G, Fuchs FD, Fuchs SC, Fujita Y, Furusawa T, Gaciong Z, Gareta D, Garnett SP, Gaspoz JM, Gasull M, Gates L, Gavrila D, Geleijnse JM, Ghasemian A, Ghimire A, Giampaoli S, Gianfagna F, Giovannelli J, Goldsmith RA, Gonçalves H, Gross MG, Rivas JP, Gottrand F, Graff-Iversen S, Grafnetter D, Grajda A, Gregor RD, Grodzicki T, Grøntved A, Gruden G, Grujic V, Gu D, Guan OP, Gudnason V, Guerrero R, Guessous I, Guimaraes AL, Gulliford MC, Gunnlaugsdottir J, Gunter M, Gupta PC, Gureje O, Gurzkowska B, Gutierrez L, Gutzwiller F, Hadaegh F, Halkjær J, Hambleton IR, Hardy R, Harikumar R, Hata J, Hayes AJ, He J, Hendriks ME, Henriques A, Cadena LH, Herrala S, Heshmat R, Hihtaniemi IT, Ho SY, Ho SC, Hobbs M, Hofman A, Dinc GH, Hormiga CM, Horta BL, Houti L, Howitt C, Htay TT, Htet AS, Hu Y, Huerta JM, Husseini AS, Huybrechts I, Hwalla N, lacoviello L, lannone AG, Ibrahim MM, Ikram MA, Irazola VE, Islam M, Ivkovic V, Iwasaki M, Jackson RT, Jacobs JM, Jafar $T$, Jamrozik K, Janszky I, Jasienska $G$, Jelakovic $B$, Jiang $C Q$, Joffres $M$, Johansson $M$, Jonas JB, Jørgensen $T$, Joshi $P$, Juolevi $A$, Jurak G, Jureša V, Kaaks R, Kafatos A, Kalter-Leibovici O, Kamaruddin NA, Kasaeian A, Katz J, Kauhanen J, Kaur P, Kavousi M, Kazakbaeva G, 
Keil U, Boker LK, Keinänen-Kiukaanniemi S, Kelishadi R, Kemper HC, Kengne AP, Kersting $M$, Key $T$, Khader YS, Khalili D, Khang YH, Khaw KT, Kiechl S, Killewo J, Kim J, Klumbiene J, Kolle E, Kolsteren P, Korrovits P, Koskinen S, Kouda K, Koziel S, Kristensen PL, Krokstad $S$, Kromhout D, Kruger HS, Kubinova R, Kuciene R, Kuh D, Kujala UM, Kula K, Kulaga Z, Kumar RK, Kurjata P, Kusuma YS, Kuulasmaa $\mathrm{K}$, Kyobutungi $\mathrm{C}$, Laatikainen $\mathrm{T}$, Lachat $\mathrm{C}$, Lam TH, Landrove $\mathrm{O}$, Lanska V, Lappas G, Larijani B, Laugsand LE, Laxmaiah A, Bao KL, Le TD, Leclercq $C$, Lee J, Lee J, Lehtimäki T, Lekhraj R, León-Muñoz LM, Levitt NS, Li Y, Lilly CL, Lim WY, Lima-Costa MF, Lin HH, Lin $X$, Linneberg $A$, Lissner $L$, Litwin $M$, Lorbeer $R$, Lotufo PA, Lozano JE, Luksiene D, Lundqvist A, Lunet N, Lytsy P, Ma G, Ma J, MachadoCoelho GL, Machi S, Maggi S, Magliano DJ, Majer M, Makdisse M, Malekzadeh R, Malhotra R, Rao KM, Malyutina S, Manios $Y$, Mann Jl, Manzato E, Margozzini P, Marques-Vidal P, Marrugat J, Martorell R, Mathiesen EB, Matijasevich A, Matsha TE, Mbanya JC, Posso AJ, McFarlane SR, McGarvey ST, McLachlan S, McLean RM, McNulty BA, Khir AS, Mediene-Benchekor S, Medzioniene J, Meirhaeghe A, Meisinger C, Menezes AM, Menon GR, Meshram II, Metspalu A, Mi J, Mikkel K, Miller JC, Miquel JF, Mišigoj-Durakovic M, Mohamed MK, Mohammad K, Mohammadifard N, Mohan V, Yusoff MF, Møller NC, Molnár D, Momenan A, Mondo CK, Monyeki KD, Moreira LB, Morejon A, Moreno LA, Morgan K, Moschonis G, Mossakowska M, Mostafa A, Mota J, Motlagh ME, Motta J, Muiesan ML, MüllerNurasyid M, Murphy N, Mursu J, Musil V, Nagel G, Naidu BM, Nakamura $H$, Námešná J, Nang EE, Nangia VB, Narake S, NavarreteMuñoz EM, Ndiaye NC, Neal WA, Nenko I, Nervi F, Nguyen ND, Nguyen QN, Nieto-Martínez RE, Niiranen TJ, Ning G, Ninomiya T, Nishtar S, Noale M, Noboa OA, Noorbala AA, Noorbala T, Noto D, Al Nsour M, O'Reilly D, Oh K, Olinto MT, Oliveira IO, Omar MA, Onat A, Ordunez P, Osmond C, Ostojic SM, Otero JA, Overvad K, Owusu-Dabo E, Paccaud FM, Padez C, Pahomova E, Pajak A, Palli D, Palmieri L, Panda-Jonas S, Panza F, Papandreou D, Parnell WR, Parsaeian M, Pecin I, Pednekar MS, Peer N, Peeters PH, Peixoto SV, Pelletier C, Peltonen M, Pereira AC, Pérez RM, Peters A, Petkeviciene J, Pham ST, Pigeot I, Pikhart H, Pilav A, Pilotto L, Pitakaka F, Plans-Rubió $P$, Polakowska $M$, Polašek $O$, Porta $M$, Portegies $M L$, Pourshams A, Pradeepa R, Prashant M, Price JF, Puiu M, Punab M, Qasrawi RF, Qorbani M, Radic I, Radisauskas R, Rahman M, Raitakari O, Raj M, Rao SR, Ramachandran A, Ramos E, Rampal S, Reina DA, Rasmussen F, Redon J, Reganit PF, Ribeiro R, Riboli E, Rigo F, de Wit TF, Ritti-Dias RM, Robinson SM, Robitaille C, Rodríguez-Artalejo $F$, Rodriguez-Perez del Cristo $M$, Rodríguez-Villamizar LA, RojasMartinez R, Rosengren A, Rubinstein A, Rui O, Ruiz-Betancourt BS, Horimoto AR, Rutkowski M, Sabanayagam C, Sachdev HS, Saidi O, Sakarya S, Salanave B, Salazar Martinez E, Salmerón D, Salomaa V, Salonen JT, Salvetti M, Sánchez-Abanto J, Sans S, Santos D, Santos IS, dos Santos RN, Santos R, Saramies JL, Sardinha LB, Margolis GS, Sarrafzadegan N, Saum KU, Savva SC, Scazufca M, Schargrodsky H, Schneider IJ, Schultsz C, Schutte AE, Sen A, Senbanjo IO, Sepanlou SG, Sharma SK, Shaw JE, Shibuya K, Shin DW, Shin Y, Siantar R, Sibai AM, Silva DA, Simon $M$, Simons J, Simons LA, Sjöström $M$, Skovbjerg S, Slowikowska-Hilczer J, Slusarczyk P, Smeeth L, Smith $M C$, Snijder MB, So HK, Sobngwi E, Söderberg S, Solfrizzi V, Sonestedt $E$, Song $Y$, Sørensen $\mathrm{Tl}$, Jérome $C S$, Soumare $A$, Staessen JA, Starc G, Stathopoulou MG, Stavreski B, Steene-Johannessen J, Stehle P, Stein AD, Stergiou GS, Stessman J, Stieber J, Stöckl D, Stocks T, Stokwiszewski J, Stronks K, Strufaldi MW, Sun CA, Sundström
J, Sung $Y T$, Suriyawongpaisal $P$, Sy RG, Tai ES, Tammesoo ML, Tamosiunas A, Tang L, Tang X, Tanser F, Tao Y, Tarawneh MR, Tarqui-Mamani CB, Taylor A, Theobald H, Thijs L, Thuesen BH, Tjonneland A, Tolonen HK, Tolstrup JS, Topbas M, Topór-Madry R, Tormo MJ, Torrent M, Traissac P, Trichopoulos D, Trichopoulou A, Trinh OT, Trivedi A, Tshepo L, Tulloch-Reid MK, Tuomainen TP, Tuomilehto J, Turley ML, Tynelius P, Tzourio C, Ueda P, Ugel E, Ulmer H, Uusitalo HM, Valdivia G, Valvi D, van der Schouw YT, Van Herck $K$, van Rossem L, van Valkengoed IG, Vanderschueren D, Vanuzzo $D$, Vatten L, Vega T, Velasquez-Melendez G, Veronesi G, Verschuren WM, Verstraeten R, Victora CG, Viet $L$, Viikari-Juntura $E$, Vineis $P$, Vioque J, Virtanen JK, Visvikis-Siest $S$, Viswanathan $B$, Vollenweider P, Voutilainen S, Vrdoljak A, Vrijheid M, Wade AN, Wagner A, Walton J, Mohamud WN, Wang MD, Wang Q, Wang YX, Wannamethee SG, Wareham N, Wederkopp N, Weerasekera D, Whincup PH, Widhalm K, Widyahening IS, Wiecek A, Wijga AH, Wilks RJ, Willeit J, Willeit $P$, Williams EA, Wilsgaard T, Wojtyniak B, Wong TY, Wong-McClure RA, Woo J, Woodward M, Wu AG, Wu FC, Wu SL, Xu H, Yan W, Yang $X, Y e X$, Yiallouros $P K$, Yoshihara A, Younger-Coleman NO, Yusoff AF, Yusoff MF, Zambon S, Zdrojewski T, Zeng $Y$, Zhao D, Zhao W, Zheng Y, Zhu D, Zimmermann E, Zuñiga Cisneros J; NCD Risk Factor Collaboration (NCD-RisC). Worldwide trends in blood pressure from 1975 to 2015: a pooled analysis of 1479 populationbased measurement studies with 19.1 million participants. Lancet 2017;389:37-55.

6. Benjamin EJ, Virani SS, Callaway CW, Chamberlain AM, Chang AR, Cheng S, Chiuve SE, Cushman M, Delling FN, Deo R, de Ferranti $S D$, Ferguson JF, Fornage $M$, Gillespie $C$, Isasi $C R$, Jiménez $M C$, Jordan LC, Judd SE, Lackland D, Lichtman JH, Lisabeth L, Liu S, Longenecker CT, Lutsey PL, Mackey JS, Matchar DB, Matsushita K, Mussolino ME, Nasir K, O'Flaherty M, Palaniappan LP, Pandey A, Pandey DK, Reeves MJ, Ritchey MD, Rodriguez CJ, Roth GA, Rosamond WD, Sampson UK, Satou GM, Shah SH, Spartano NL, Tirschwell DL, Tsao CW, Voeks JH, Willey JZ, Wilkins JT, Wu JH, Alger HM, Wong SS, Muntner P; American Heart Association Council on Epidemiology and Prevention Statistics Committee and Stroke Statistics Subcommittee. Heart disease and stroke statistics-2018 update: a report from the American Heart Association. Circulation 2018;137:e67-492.

7. Whelton PK, Carey RM, Aronow WS, Casey DE Jr, Collins KJ, Dennison Himmelfarb C, DePalma SM, Gidding S, Jamerson KA, Jones DW, MacLaughlin EJ, Muntner P, Ovbiagele B, Smith SC Jr, Spencer CC, Stafford RS, Taler SJ, Thomas RJ, Williams KA Sr, Williamson JD, Wright JT Jr. 2017 ACC/AHA/AAPA/ABC/ACPM/AGS/ APhA/ASH/ASPC/NMA/PCNA guideline for the prevention, detection, evaluation, and management of high blood pressure in adults: a report of the American College of Cardiology/American Heart Association task force on clinical practice guidelines. Hypertension 2018;71:e13-115.

8. Malik AH, Akram Y, Shetty S, Malik SS, Yanchou Njike V. Impact of sugar-sweetened beverages on blood pressure. Am J Cardiol 2014;113:1574-80.

9. Sacks FM, Svetkey LP, Vollmer WM, Appel $\sqcup$, Bray GA, Harsha D, Obarzanek E, Conlin PR, Miller ER 3rd, Simons-Morton DG, Karanja $\mathrm{N}$, Lin PH, Aickin M, Most-Windhauser MM, Moore TJ, Proschan MA, Cutler JA; DASH-Sodium Collaborative Research Group. Effects on blood pressure of reduced dietary sodium and the Dietary Approaches to Stop Hypertension (DASH) diet. N Engl J Med 
2001;344:3-10.

10. Wang L, Manson JE, Forman JP, Gaziano JM, Buring JE, Sesso HD. Dietary fatty acids and the risk of hypertension in middle-aged and older women. Hypertension 2010;56:598-604.

11. Jose PO, Frank AT, Kapphahn Kl, Goldstein BA, Eggleston K, Hastings KG, Cullen MR, Palaniappan LP. Cardiovascular disease mortality in Asian Americans. J Am Coll Cardiol 2014;64:2486-94.

12. Ye J, Rust $G$, Baltrus $P$, Daniels E. Cardiovascular risk factors among Asian Americans: results from a National Health Survey. Ann Epidemiol 2009;19:718-23.

13. Kim H, Yoo S, Cho S, Kwon EJ, Kim S, Park JY. Health status and associated health risks among female marriage immigrants in Korea. Korean J Health Educ Promot 2010;27:79-89.

14. Alejandro RG. The Food of the Philippines: 81 Easy and Delicious Recipes from the Pearl of the Orient. Clarendon (VT): Tuttle Publishing; 2005. p.17.

15. Castillo-Carandang NT, Sison OT, Velandria FV, Sy RG, Llanes EJ, Reganit PF, Gumatay WA, Punzalan FE. "You are what you eat:" self-reported preferences for food taste and cooking methods of adult Filipinos (20-50 years old). Acta Med Philipp 2014;48:56-61.

16. Bouchon P. Understanding oil absorption during deep-fat frying. Adv Food Nutr Res 2009;57:209-34.

17. Dana D, Saguy IS. Mechanism of oil uptake during deep-fat frying and the surfactant effect-theory and myth. Adv Colloid Interface Sci 2006;128-130:267-72

18. Jaarin K, Masbah N, Nordin SH. Heated cooking oils and its effect on blood pressure and possible mechanism: a review. Int J Clin Exp Med 2016;9:626-36.

19. Brandes RP. Endothelial dysfunction and hypertension. Hypertension 2014;64:924-8.

20. Higashi Y, Noma K, Yoshizumi M, Kihara Y. Endothelial function and oxidative stress in cardiovascular diseases. Circ J 2009;73:411-8.

21. Leong $\mathrm{X}, \mathrm{Ng} \mathrm{C}$, Jaarin $\mathrm{K}$, Mustafa $\mathrm{M}$. Effects of repeated heating of cooking oils on antioxidant content and endothelial function. Austin J Pharmacol Ther 2015;3:1068.

22. Schulz $E$, Gori T, Münzel T. Oxidative stress and endothelial dysfunction in hypertension. Hypertens Res 2011;34:665-73.

23. Sayon-Orea C, Bes-Rastrollo M, Gea A, Zazpe I, Basterra-Gortari FJ, Martinez-Gonzalez MA. Reported fried food consumption and the incidence of hypertension in a Mediterranean cohort: the SUN (Seguimiento Universidad de Navarra) project. Br J Nutr 2014;112: 984-91.

24. Sayon-Orea C, Martinez-Gonzalez MA, Gea A, Flores-Gomez E, Basterra-Gortari FJ, Bes-Rastrollo M. Consumption of fried foods and risk of metabolic syndrome: the SUN cohort study. Clin Nutr 2014;33:545-9.

25. Soriguer F, Rojo-Martínez G, Dobarganes MC, García Almeida JM Esteva I, Beltrán M, Ruiz De Adana MS, Tinahones F, GómezZumaquero JM, García-Fuentes E, González-Romero S. Hypertension is related to the degradation of dietary frying oils. Am J Clin Nutr 2003;78:1092-7.

26. Kang Y, Kim J. Association between fried food consumption and hypertension in Korean adults. Br J Nutr 2016;115:87-94.
27. Abris GP, Hong S, Provido SM, Lee JE, Lee CB. Filipino women's diet and health study (FiLWHEL): design and methods. Nutr Res Pract 2017;11:70-5

28. Abris GP, Kim NH, Provido SM, Hong S, Yu SH, Lee CB, Lee JE. Dietary diversity and nutritional adequacy among married Filipino immigrant women: The Filipino Women's Diet and Health Study (FiLWHEL). BMC Public Health 2018;18:359.

29. Abris GP, Provido SM, Hong S, Yu SH, Lee CB, Lee JE. Association between dietary diversity and obesity in the Filipino Women's Diet and Health Study (FiLWHEL): a cross-sectional study. PLoS One 2018;13:e0206490.

30. USDA Food Composition Database [Internet]. Washington, D.C. USDA; 2019 [cited 2018 October 24]. Available from: https://ndb.nal. usda.gov/ndb/.

31. National Academy of Agricultural Sciences. Standard food composition table 8th revision [Internet]. Wanju: National Academy of Agricultural Sciences; 2011 [cited 2018 October 24]. Available from: http://koreanfood.rda.go.kr/eng/fctFoodSrchEng/engMain.

32. Food and Nutrition Research Institute (FNRI). The Philippine Food Composition Tables. Manila: FNRI-DOST; 1997.

33. WHO Expert Consultation. Appropriate body-mass index for Asian populations and its implications for policy and intervention strategies. Lancet 2004;363:157-63.

34. Ng CY, Leong XF, Masbah N, Adam SK, Kamisah Y, Jaarin K. Heated vegetable oils and cardiovascular disease risk factors. Vascul Pharmacol 2014;61:1-9.

35. Choe E, Min DB. Chemistry of deep-fat frying oils. J Food Sci 2007;72:R77-86

36. Falade AO, Oboh G, Okoh Al. Potential health implications of the consumption of thermally-oxidized cooking oils-a review. Pol J Food Nutr Sci 2017:67:95-106.

37. Briones AM, Touyz RM. Oxidative stress and hypertension: current concepts. Curr Hypertens Rep 2010;12:135-42.

38. Armas-Padilla MC, Armas-Hernández MU, Sosa-Canache B, Cammarata R, Pacheco B, Guerrero J, Carvajal AR, Hernández-Hernández R, Israili $\mathrm{ZH}$, Valasco $M$. Nitric oxide and malondialdehyde in human hypertension. Am J Ther 2007;14:172-6.

39. Hitomi $\mathrm{H}$, Kiyomoto $\mathrm{H}$, Nishiyama A. Angiotensin II and oxidative stress. Curr Opin Cardiol 2007;22:311-5.

40. Zhang Q, Saleh AS, Chen J, Shen Q. Chemical alterations taken place during deep-fat frying based on certain reaction products: a review. Chem Phys Lipids 2012;165:662-81.

41. Nayak PK, Dash U, Rayaguru K, Krishnan KR. Physio-chemical changes during repeated frying of cooked oil: a review. J Food Biochem 2016;40:371-90.

42. Kanner J. Dietary advanced lipid oxidation endproducts are risk factors to human health. Mol Nutr Food Res 2007;51:1094-101.

43. Andrikopoulos NK, Dedoussis GV, Falirea A, Kalogeropoulos N, Hatzinikola HS. Deterioration of natural antioxidant species of vegetable edible oils during the domestic deep-frying and pan-frying of potatoes. Int J Food Sci Nutr 2002;53:351-63.

44. Goburdhun D, Jhurree B. Effect of deep-fat frying on fat oxidation in soybean oil. Int J Food Sci Nutr 1995;46:363-71. 